\title{
An Experimental Study on the Response of Model Footings Resting on Reinforced Flyash Beds under Repeated Load
}

\author{
Shivaram Gangadhara and Honnagondanahalli Chikkaranganna Muddaraju \\ Department of Civil Engineering, Bangalore University, Bangalore 560 056, India
}

\begin{abstract}
In the present, investigation an attempt has been made to study the behavior of reinforced flyash beds under repeated loads by conducting carefully designed experiments. The main objective of the experiments conducted is to evaluate the beneficial effects of using flyash as a backfill material in the reinforced beds to resist the repeated loads. As no unique standard equipment is available for the application of repeated loads and to measure the response, different researchers have designed and fabricated different types of equipments for the testing. The repeated load of known intensity with waveform type and frequency is applied on the surface and embedded footing in unreinforced and reinforced flyash beds. The response of the flyash beds, in the form of settlement is measured using linear variable differential transducers. The experimental results clearly demonstrated that the provision of reinforcement in the flyash beds is effective in improving the performance of both surface and embedded footing under repeated loads.
\end{abstract}

Key words: Reinforced fly ash bed, repeated loads, cyclic resistance ratio, settlement ratio.

\section{Introduction}

The simple mechanism of reinforced earth and the economy in cost and time have made it instant success with research workers and construction engineers alike for temporary as well as permanent structures. The performance of reinforced earth when exposed to dynamic loading is a critical issue, since the behavior of these structures under monotonic loading has been understood to some fair degree of satisfaction. However, understanding the dynamic behavior of reinforced soils is essential in areas where the seismic or man-made dynamic loading occurs.

The performance and behavior of reinforced soil structure both in the field and the laboratory are well documented. Many researchers have contributed immensely to the better understanding of the concepts, design procedures and construction methods of

Corresponding author: Shivaram Gangadhara, Ph.D., research fields: reinforced soils and expansive soils. E-mail: gdhara_68@yahoo.com. reinforced soil structures through laboratory studies, field investigations and monitoring of constructed structures [1-4]. Efforts to study the behavior of reinforced earth structures when exposed to repeated loading are very scanty [5-7] .

Flyash generated by thermal power plant, an industrial waste slag, generally posses good engineering properties, one important engineering property being its strength that is necessary for using non-Pozzolonic flyash in any geotechnical applications. To achieve a higher strength, inclusion of geogrid reinforcement into compacted flyash is one of the most effective techniques. Several attempts have been made in the laboratory to study the behavior of reinforced flyash beds. All such efforts are mainly focused on understanding the bearing capacity and settlement behavior of the reinforced fly ash beds. However, efforts to study the behavior of reinforced fly ash beds when subjected to the repeated loading are scanty.

In this investigation, it is intended to investigate the 
potential benefits of using reinforced earth concept to improve the performance of surface and embedded footings in flyash beds under repeated loading. The experiments are conducted on model footing resting on/in reinforced and unreinforced flyash beds subjected to repeated loads. The flyash beds were reinforced with geogrids. Model footing used for this investigation is mild steel square footing of $100 \mathrm{~mm}$ size and $4 \mathrm{~mm}$ thick. The experimental results presented earlier had shown that the performance of footing is strongly influenced by the pattern of reinforcement distribution and the excitation parameters Nagaraja [8]. Hence in the present investigation, it is intend to study the performance of both surface and embedded footings as influenced by the number of reinforcement layers in the flyash beds. Reinforcement location and spacing were based on optimization of previous research results. In the present study, the repeated load tests are performed in an ADTA (automated dynamic testing apparatus) specially designed, fabricated and calibrated for the purpose.

\section{Materials and Methods}

\subsection{Flyash}

The fly ash used in the study is collected from Raichur thermal power plant, Karnataka, India. It is a non-pozzolanic fly ash belonging to ASTM (American Society for Testing Materials) classification "C". This fly ash is directly collected from open dry dumps. The property of flyash is given in Table 1.

\subsection{Reinforcement}

Polyethylene reinforcement in the form of geogrid is used in the present investigation. Table 2 presents the properties of geogrid used.

\subsection{Preparation of Flyash Beds}

Fly ash bed is prepared by manual compaction at its optimum moisture content, to maximum dry density.
Unreinforced sample is compacted up to a height of $360 \mathrm{~mm}$ in three equal layers of $120 \mathrm{~mm}$ thick. For reinforced sample, the geogrid reinforcements are placed at predetermined spacing in between fly ash layers from the bottom of footing, and by the same procedure remaining height of the tank is compacted. The reinforcements are provided in the shape of circular discs. A clearance of $5 \mathrm{~mm}$ is provided to ensure that no friction was generated between the reinforcement and the walls of the tank.

\subsection{Method of Testing}

The reinforced and unreinforced fly ash beds are subjected to repeated loading in the ADTA. The excitation values, viz., cyclic pressure (repeated load) and frequency are selected and fed in to the computer. The load is applied on to the model footing and the settlements are measured through three different LVDTs (linear variable differential transducers) placed orthogonal to each other. The load cell and the

Table 1 Properties of fly ash.

\begin{tabular}{ll}
\hline Physical properties & Test results \\
\hline Colour & Light grey \\
Specific gravity & 2.07 \\
Grain size distribution & - \\
Sand size fraction (\%) & 15 \\
Silt and clay size fraction (\%) & 85 \\
Atterberg's limits & - \\
Liquid Limit (\%) & 31.8 \\
Plastic Limit (\%) & - \\
Plasticity Index (\%) & Non plastic \\
Compaction characteristics & - \\
Optimum moisture content (\%) & 23 \\
MDD (maximum dry density) $\left(\mathrm{kN} / \mathrm{m}^{3}\right)$ & 12.7 \\
Unconfined compressive strength at & 51.4 \\
MDD (kPa) & \\
\hline
\end{tabular}

Table 2 Properties of reinforcement.

\begin{tabular}{llll}
\hline Physical properties & \multicolumn{2}{l}{ Direction Unit } & Test results \\
\hline \multirow{2}{*}{ Aperture size } & $\mathrm{MD}$ & $\mathrm{mm}$ & 34 \\
& $\mathrm{CD}$ & $\mathrm{mm}$ & 32 \\
\hline \multirow{2}{*}{ Ultimate tensile strength } & $\mathrm{MD}$ & $\mathrm{kN} / \mathrm{m}$ & 33.2 \\
& $\mathrm{CD}$ & $\mathrm{kN} / \mathrm{m}$ & 31.1 \\
\hline \multirow{2}{*}{ Strain at ultimate } & $\mathrm{MD}$ & $\%$ & 14.4 \\
& $\mathrm{CD}$ & $\%$ & 6.9 \\
\hline
\end{tabular}

$\mathrm{MD}$ - Machine direction, $\mathrm{CD}$-Cross machine direction. 
Linear variable differential transducers are in turn connected to the control unit, where the analog to digital conversion takes place, and is recorded in the data acquisition system. The measured settlements after each cycle of loading are recorded in the data acquisition system, which is then recovered through the computer.

\section{Results and Discussion}

To bring out the effect of inclusion of geogrid reinforcement on the performance of surface and embedded square footing resting on/in flyash beds, experiments are conducted both on unreinforced and reinforced flyash beds under repeated loading. Fig. 1 presents the number of load cycles $\mathrm{v} / \mathrm{s}$ settlement curves for square surface footing resting on unreinforced and reinforced flyash beds with two and three layers of reinforcement layers subjected to a repeated loading of $250 \mathrm{kPa}$. It can be seen from the figure that at any level of settlement, the footing resting on reinforced fly ash bed, both two layer and three layer, resisted more number of load cycles compared to their counterpart resting on unreinforced flyash bed. For example, at a settlement of $10 \mathrm{~mm}$, the footing on unreinforced flyash bed resisted eight repetitive loading whereas its counterpart resting on two and three layer reinforced flyash beds resisted about 300 repetitions and 9,000 repetitions. This clearly demonstrate the effectiveness of inclusion of geogrid reinforcement in flyash beds. Further it is to be observed from Fig. 1 that among the footing on reinforced flyash beds, footing on three layer reinforced flyash bed performed better than footing on two layer reinforced flyash bed. This result clearly confirms the trend of results of earlier researcher which established the fact that the optimum number of reinforcement layer is three. Fig. 2 presents the number of load cycles $\mathrm{v} / \mathrm{s}$ settlement curves for embedded footing in unreinforced and reinforced fly ash beds with two and three layers of reinforcement subjected to a repeated loading of $250 \mathrm{kPa}$. It can be observed from Fig. 2 that the trend of results in case of embedded footing is same as that for surface footing (Fig. 1). Fig. 2 demonstrates that even for the embedded footing:

- The reinforced flyash beds experience less settlement compared to the unreinforced flyash beds at the same number of repeated loads;

- The three layer of reinforcement is optimum, which induces minimum settlement of the embedded footing at any number of load cycles.

A comparative study of Figs. 1 and 2 indicates that, both in the unreinforced and reinforced flyash beds, the embedded footing experiences relatively higher value of settlement compared to the surface footing. This is true irrespective of number of layer of reinforcement. Similarly in case of reinforced flyash beds, the surface footing in three layer reinforced flyash bed experienced a settlement of $2 \mathrm{~mm}$ where as its counterpart embedded in three layer flyash bed experienced a settlement of $7 \mathrm{~mm}$ for the same 50

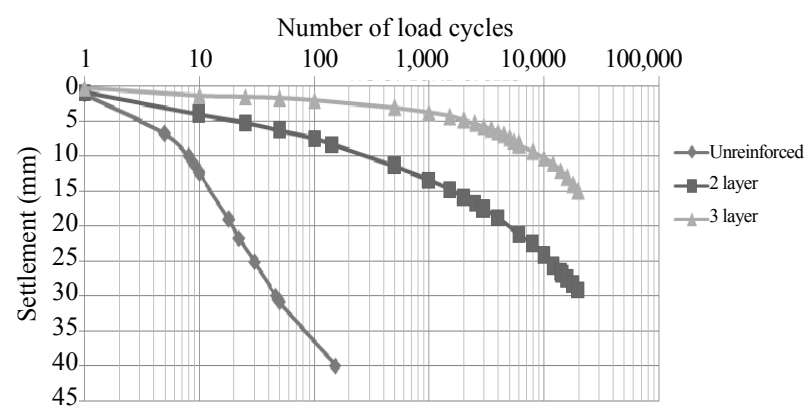

Fig. 1 Effect of number reinforcement (Spacing, $S=0.3 \mathrm{~B}$ ) on the performance of surface footing resting on flyash beds under a repeated load of $250 \mathrm{kPa}$.

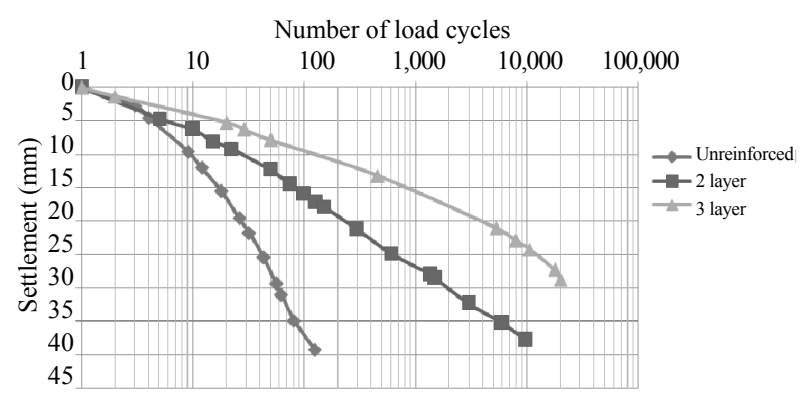

Fig. 2 Effect of number reinforcement $(S=0.3 B)$ on the performance of embedded footing resting in flyash beds under a repeated load of $250 \mathrm{kPa}$. 
number of repetitions. This clearly demonstrates that the surface footing resting on unreinforced/reinforced flyash beds perform better than the embedded footing in unreinforced/reinforced flyash beds. This is further analyzed in terms of cyclic resistance ratio and settlement ratio.

The results of the experiments performed to understand the behavior of surface and embedded footing are analyzed in terms of CRR (cyclic resistance ratio) and the SR (settlement ratio) using the definitions given by Nagaraja [8].

Number of load cycles required to cause a $C R R=\frac{\text { settlement of } \mathrm{S} \text { in reinforced specimen }}{\text { Number of load cycles required to cause a }}$ settlement of $\mathrm{S}$ in unreinforc ed specimen

\subsection{CRR (Cyclic Resistance Ratio)}

Figs. 3 and 4 present the cyclic resistance ratio curves for square footing and embedded footing resting on/in two layer and three layer reinforced flyash beds. It is seen from these figures that the cyclic resistance ratio for both surface and embedded footing increases as the settlement of the footing increases. At lesser value of settlement, the cyclic resistance ratio is less and increases exponentially at higher values of settlement. For example, for surface footing at a settlement of $20 \mathrm{~mm}$ the cyclic resistance ratio is 40 and it increases to about 100 at settlement of $30 \mathrm{~mm}$. Similarly for embedded footing these values are 5 and 42 at $20 \mathrm{~mm}$ and $30 \mathrm{~mm}$ settlement, respectively. This clearly demonstrates that the provision of reinforcement is effective in increasing the repeated load carrying capacity both in surface footing and embedded footing. Further, it can be inferred that providing the reinforcement is more effective or becomes more useful at higher values of settlement (as indicated by higher values of cyclic resistance ratio at higher settlement level). Further a comparison of these curves indicates that at any settlement level, the surface footing exhibits higher values of cyclic resistance ratio compared to its counterpart embedded in flyash beds. For example, in two layered flyash beds, the surface footing at a settlement of $20 \mathrm{~mm}$ exhibits a cyclic resistance ratio of 38 whereas the embedded footing at the same settlement level exhibits a cyclic resistance ration of about 5 only (Fig. 3). Similarly at $30 \mathrm{~mm}$ settlement level, the cyclic resistance ratio values of surface and embedded footing are 90 and 40, respectively (Fig. 3).

Similar trend of results is observed in case of three layer reinforced flyash beds also (Fig. 4), i.e., the surface footing exhibited higher values of cyclic resistance ratio compared to the embedded footings. It is further interesting to observe from Figs. 3 and 4 that the footings, both surface and embedded, in three layer reinforced flyash beds (Fig. 4) exhibited higher values of cyclic resistance ratio compared to their counterparts in two layer reinforced flyash beds (Fig. 3). The surface footing on three layer reinforced flyash bed exhibited a cyclic resistance ratio as high as

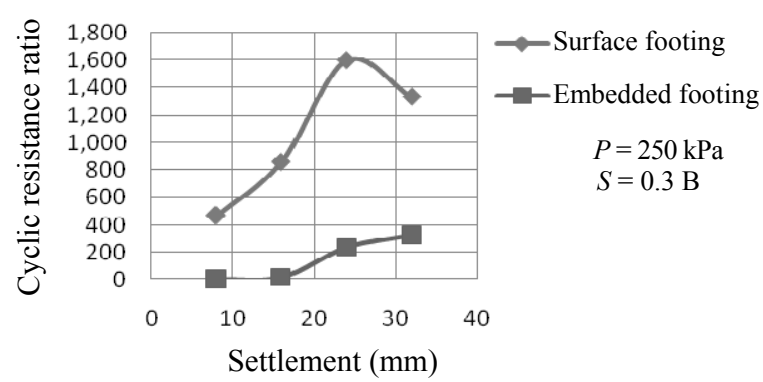

Fig. 4 Cyclic resistance ratio curves for footing in three layer reinforced flyash beds.

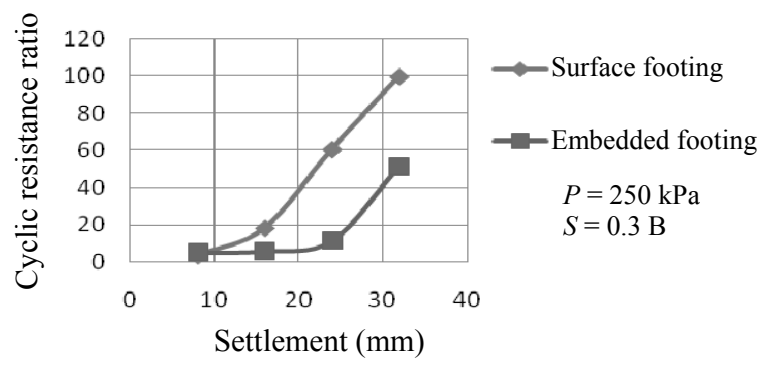

Fig. 3 Cyclic resistance ratio curves for footing in two layer reinforced flyash beds. 
1,600 at about $25 \mathrm{~mm}$ settlement level whereas the same value reduces to about 60 for two layer reinforced flyash beds. The two layer reinforced flyash beds showed a maximum cyclic resistance ratio value of 100 only (at about $30 \mathrm{~mm}$ settlement). From the above discussion it can be inferred, beyond doubt, that the optimum reinforcement number is three, for both surface and embedded footing under repeated loads.

\subsection{SR (Settlement Ratio)}

To bring out the effect of reinforcement on the settlement behavior of footings in the term flyash beds, Settlement ratio is calculated from the experimental results. In the present study, SR (settlement ratio) is defined as:

$$
S R=\frac{\begin{array}{c}
\text { Settlement of reinforced flyash bed } \\
\text { after } \mathrm{N} \text { number of cycles }
\end{array}}{\begin{array}{c}
\text { Settlement of unreinforc ed flyash bed } \\
\text { after N number of cycles }
\end{array}}
$$

Figs. 5 and 6 present the settlement ratio curves for surface and embedded footing resting on/in reinforced flyash beds with two and three layer of reinforcement, respectively under repeated load of $250 \mathrm{kPa}$. It is to be observed in these two figures that the settlement ratio is calculated to a maximum of 100 number of load cycles, through the experiments were conducted up to 20,000 load cycles for reinforced flyash beds as the experiments are terminated after 100 number of load cycles for the unreinforced flyash beds. The footing in unreinforced flyash beds experienced the limiting settlement of $40 \mathrm{~mm}$ at 100 numbers of load cycles itself. Figs. 5 and 6 show that, for all the testing conditions, at any number of load cycles the embedded footing exhibits, higher value of settlement ratio compared to the surface footing resting on reinforced flyash beds experiences less settlement compared to the embedded footing in reinforced flyash beds. The same trend of results is observed in case of both two layered and three layered reinforced flyash beds.

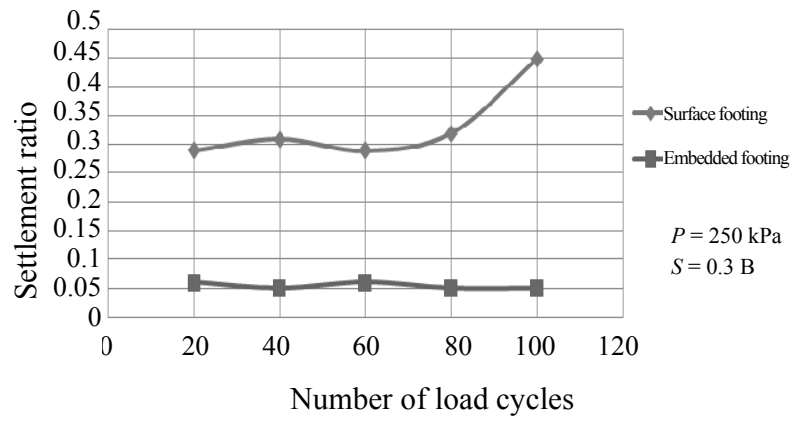

Fig. 5 Settlement ratio curves for footings in two layer reinforced flyash beds.

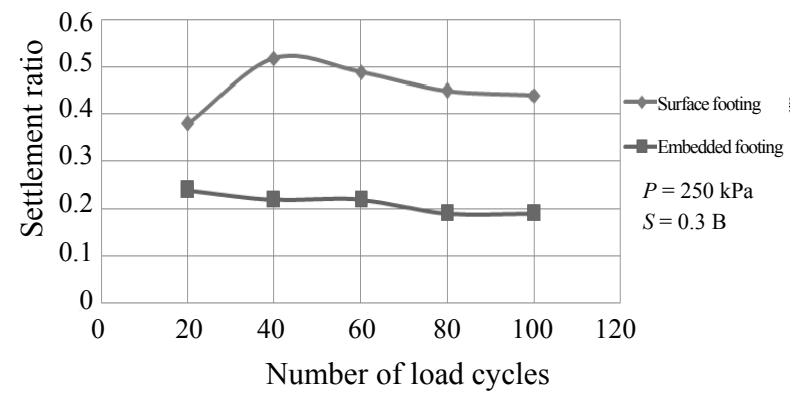

Fig. 6 Settlement ratio curves for footings in three layer reinforced flyash beds.

\section{Conclusions and Future Work}

Based on the results of experiments conducted, the following conclusions are drawn:

- Both the surface and embedded footing perform better when they are placed on/in reinforced flyash beds. Footings in reinforced flyash beds exhibit resistance for more number of repeated loads and show less settlement for a given number of repetitions compared to the unreinforced condition;

- The performance of footings is calculated in terms of cyclic resistance ratio and settlement ratio. The surface footing exhibited higher values of cyclic resistance ratio and lower values of settlement ratio under all testing conditions, indicating that they perform better than the embedded footing;

- The cyclic resistance ratio curves and the settlement ratio curves indicate that the optimum number of reinforcement layer is three.

The following future work are drawn: 
- Tests can be performed with a combination of monotonic and repeated loading, simulating some actual field condition of loading;

- The effect of rising water table may be tested in the laboratory by conducting repeated load tests in presence of water.

\section{References}

[1] A.K. Bera, S.N. Chandra, A. Ghosh, Unconfined compressive strength of fly ash reinforced with jute geotextiles, Geotextiles and Geomembranes 27 (4) (2009) 391-398.

[2] S. Ayyappan, K. Hemalatha, M. Sundaram, Investigation of engineering behavior of soil, polypropylene fibers and flyash mixtures for road construction, International Journal of Environmental Science and Development 1 (2) (2010) 171-175.

[3] A.K. Choudhary, J.N. Jha, K.S. Gill, Laboratory investigation of bearing capacity behaviour of strip footing on reinforced flyash slope, Geotextiles and Geomembranes 28 (4) (2010) 393-402.

[4] D.S.V. Prasad, M. Anjan Kumar, G.V.R.P. Raju, V. Kondayya, Behaviour of flyash reinforced sub-bases on expansive soil subgrades under cyclic loading, in: Indian Geotechnical Conference, Mumbai, 2010, p. 131.

[5] E.C. Shin, B.M. Das, Dynamic behaviour of Geogrid reinforced sand, Journal of Geotechnical Engineering 3 (4) (1999) 379-386.

[6] N.A. el Mahallawy, A.S. Rashed, Experimental study for the behaviour of footings on reinforced sand beds overlying soft clay zone, Journal of American Science 8 (1) (2012) 427-434.

[7] A.F. Zidan, Numerical study of behaviour of Circular footing on geogrid reinforced sand under static and dynamic loading, Journal of Geotechnical Engineerng 30 (2012) 499-510.

[8] P.S. Nagaraja, Behavior of model footing resting on geogrid reinforced sand beds under monotonic, cyclic and dynamic loads, Ph.D. Thesis, Bangalore University, Bangalore, 2006. 